\title{
Psychometric Properties of the Brazilian Version of the Revised Illness Perception Questionnaire for Healthy Women (IPQ-RH)
}

\author{
Rebeca Veras de Andrade Vieira ${ }^{1}$ \\ Juliana Burges Sbicigo ${ }^{2}$ \\ Maria Júlia Armiliato ${ }^{1}$ \\ Elisa Kern de Castro ${ }^{3}$ \\ Maria João Figueiras ${ }^{4}$
}

\begin{abstract}
The Common Sense Model refers to the association between disease perception and health behaviors. This study aimed to analyze the psychometric properties of the Revised Illness Perception Questionnaire for Healthy People - (IPQ-RH) in healthy women about breast cancer. A total of 321 women participated, with a mean age of 55.72 years old $(S D=10.75)$, users of Basic Health Units. Confirmatory factor analyzes (CFAs) were carried out and the McDonald's Omega and Cronbach's alpha coefficients were calculated. The results of the CFAs confirmed the structure of seven factors for the IPQ-RH $(\mathrm{CFI}=.92$; TLI $=.91 ; \mathrm{RMSEA}=.03$; $\mathrm{SRMR}=.06$ ) and of two factors for the subscale of causes of the disease $(\mathrm{CFI}=.97$; TLI $=.97$; RMSEA $=.00$; SRMR $=.05)$. The instrument's reliability was, in general, satisfactory. The IPQ-RH has appropriate psychometric properties to investigate the illness perception in healthy women.
\end{abstract}

Keywords: breast neoplasms, self-management, psychometrics

\section{Propriedades Psicométricas da Versão Brasileira do Questionário de Percepção da Doença Revisado para Mulheres Saudáveis (IPQ-RH)}

\begin{abstract}
Resumo: O Modelo do Senso Comum aponta para a associação entre a percepção da doença e comportamentos em saúde. Este estudo teve por objetivo examinar as propriedades psicométricas do Questionário de Percepção da Doença para Pessoas Saudáveis - Revisado (IPQ-RH) em mulheres saudáveis sobre o câncer de mama. Participaram 321 mulheres, com idade média de 55,72 anos $(D P=10,75)$, usuárias de Unidades Básicas de Saúde. Foram realizadas análises fatoriais confirmatórias (AFCs) e calculados os coeficientes Ômega de McDonald e alpha de Cronbach. Os resultados das AFCs confirmaram a estrutura de sete fatores para o IPQ-RH $(\mathrm{CFI}=.92 ; \mathrm{TLI}=.91 ; \mathrm{RMSEA}=.03 ; \mathrm{SRMR}=.06)$ e de dois fatores para a subescala de causas da doença $(\mathrm{CFI}=.97 ; \mathrm{TLI}=.97 ; \mathrm{RMSEA}=.00 ; \mathrm{SRMR}=.05)$. A fidedignidade do instrumento foi, em geral, satisfatória. O IPQ-RH apresenta propriedades psicométricas adequadas para investigar a percepção da doença em mulheres saudáveis.
\end{abstract}

Palavras-chave: neoplasias mamárias, autogestão, psicometria

\section{Propriedades Psicométricas de la Versión Brasileña del Cuestionario de Percepción de la Enfermedad Revisado para Mujeres Sanas (IPQ-RH)}

\begin{abstract}
Resumen: El modelo del Senso Comum refiere que existe una asociación entre percepción dela enfermedad y conductas em salud. El objetivo de la investigación fue examinar las propiedades psicométricas del Cuestionário de Percepción de la Enfermedad para personas sanas - Revisado (IPQ-RH) en mujeres sanas con respecto al cáncer de mama. Participaron 321 mujeres, con edad media de 55,72 años $(D P=10,75)$, usuarias de la atención primaria en salud. Fueron realizadas análisis factoriales confirmatórias (AFCs) y calculados los coeficientes Omega de McDonald y alpha de Cronbach. Los resultados de las AFCs confirmaron la estructura de siete factores para el IPQ-RH $(\mathrm{CFI}=0.92 ; \mathrm{TLI}=0.91 ; \mathrm{RMSEA}=0.03 ; \mathrm{SRMR}=0.06)$ y de dos factores para la subescala de las causas de la enfermedad $(\mathrm{CFI}=0.97$; TLI $=0.97$; RMSA $=0.00$; $\mathrm{SRMR}=0.05)$. La fiabilidad del cuestionario fue, en general, satisfactoria. El IPQ-RH presenta propiedades psicométricas adecuadas para investigar la percepción de la enfermedad en mujeres sanas.
\end{abstract}

Palabras clave: neoplasmas de la mama, autogestión, psicometría

\footnotetext{
${ }^{1}$ Universidade do Vale do Rio dos Sinos, São Leopoldo-RS, Brazil

${ }^{2}$ Universidade Federal do Rio Grande do Sul, Porto Alegre-RS, Brazil

${ }^{3}$ Universidade Lusiada de Lisboa, Portugal

${ }^{4}$ Zayed University, Abu Dhabi, Emirados Árabes Unidos
}

Correspondence address: Rebeca Veras de Andrade Vieira. Universidade do Vale do Rio dos Sinos. Avenida UNISINOS, 950, São Leopoldo-RS, Brazil. CEP 93.022-000. E-mail: rebecavieirapsico@gmail.com
The Common Sense Model (CSM), also called the SelfRegulation Theory Model in Health, proposes that individuals develop beliefs or perceptions on the characteristics of various diseases from the information they have and their direct and indirect experiences with the disease subject (Leventhal et al., 2012; Leventhal, Nerenz, \& Steele, 1984). According to the CSM, these beliefs integrate the illness 
perception and are related to health behaviors, both in terms of adhering the treatment by sick people (Leventhal et al., 2012) and in adhering the preventive health practices by healthy individuals (Leventhal, Brisette, \& Leventhal, 2003). Faced with a health threat, people use their perceptions of the disease to evaluate the chance of cure or prevention, and before this estimation they adopt different health behaviors (Leventhal et al., 2012).

The assessment of the illness perception is performed using psychometric instruments that are widely used to assess different diseases. The instruments are free to use and translated into several languages (Broadbent, Petrie, Main, \& Weinman, 2006; Figueiras \& Alves, 2007; Moss-Morris et al., 2002; Weinman, Petrie, Moss-Morris, \& Horne, 1996). The Illness Perception Questionnaire (IPQ) (Weinman et al., 1996) represents the first assessment instrument created to evaluate the illness perception by people with asthma, diabetes, chronic fatigue syndrome, rheumatoid arthritis, and chronic pain. Originally, it was a measure composed of five dimensions that systematized the characteristics of the illness: identity (typical symptoms of the illness), causes (etiological factors attributed to the development of the illness), duration (illness progression and length), consequences (possible impacts caused by the disease) and control/cure (expectation of control or cure).

After additional analysis of the instrument, Moss-Morris et al. (2002) proposed a new version entitled Revised Illness Perception Questionnaire (IPQ-R), in which the coherence dimension (how much an individual thinks he knows about the disease). The control/cure dimension was divided into personal control (how much an individual thinks he can control the disease) and treatment control (treatment effectiveness perception). The timeline dimension was divided into timeline cyclical (refers to the course of the symptoms of the illness) and timeline acute/chronic. Finally, there was the addition of the emotional representation dimension (perceived emotional impact). Subsequently, an abbreviated version of this instrument was developed, named Brief Illness Perception Questionnaire (Brief IPQ) (Broadbent et al., 2006), composed of nine questions that vary on a 10-point Likert type scale and an open question about the causes of the illness. In Brazil, Nogueira, Seidl and Tróccoli (2016) applied the Brief IPQ to a sample of adults with chronic illness and found a two-factor factorial solution, namely, emotional representation and cognitive representation, being considered a valid and reliable measure to evaluate the illness perception in these patients.

Considering that the illness perception can also be associated with preventive health behaviors, Alwhaibi, Lilly, Hazard and Kelly (2019) and Figueiras and Alves (2007) adapted the IPQ-R for healthy individuals. The Revised Illness Perception Questionnaire for Healthy People (IPQ$\mathrm{RH}$ ) considers the same dimensions as the IPQ-R and was originally developed in Portuguese (Portugal) and validated in a study with 1,113 healthy people. The assessment instrument can be used to evaluate the perception of healthy individuals about different illnesses, including breast cancer
(Otaran \& Castro, 2019; Seabra et al., 2018). Brazil is in the range of countries with the highest incidence of breast cancer in the world (62.9 cases per 100,000 inhabitants), but it is ranked in the second-lowest region of mortality due to this illness, with 13 cases per 100,000 inhabitants (Ministry of Health, 2019a). Therefore, breast cancer is very present in Brazil, which brings the need for people, especially women, to be aware of its signs for early detection and greater chances of cure (Ministry of Health, 2019b).

In this context, the illness perception is very important, because what people think about a certain illness may be associated to the behaviors when facing it, including preventive behaviors (Figueiras \& Alves, 2007). It is known that perception is associated with quality of life, distress, risk perception and satisfaction with medical care (Kaptein et al., 2015), misconceptions (which do not correspond to reality) on breast cancer have been associated with psychological symptoms such as anxiety and depression (Gibbons, Groarke, \& Sweeney, 2016). In healthy women, the adjusted perception about the illness is associated with healthy selfcare (Seabra et al., 2018). A current study with healthy Brazilian women (Otaran \& Castro, 2019) showed that those with a family history had the perception that the illness was more difficult to control (perception of control), but did not have levels of distress higher than women without a history of breast cancer.

The illness perception is dynamic and individual beliefs can be adjusted when facing interventions. Thus, the assessment is essential to support interventions for prevention and health promotion, and individual interventions for treatment adherence (Jones, Smith, \& Llewellyn, 2016). Brazil lacks evidence of the validity and reliability of measures that investigate the illness perception in healthy individuals. Therefore, this study aimed to analyze the psychometric properties of the Revised Illness Perception Questionnaire for Healthy People (IPQ-RH) in healthy women about breast cancer.

\section{Method}

\section{Participants}

A total of 320 women were included in the study with a mean age of 55.72 years old $(S D=10.75)$, users of the Basic Health Unit, located in a large city in southern Brazil. The inclusion criterion was to be older than 25 years old and younger than 80 years old. Exclusion criteria were being pregnant and having previously had breast cancer. Among the participants, $46.7 \%$ of them $(n=152)$ had finished high school, $34.4 \%(n=112)$ of the participants finished elementary school and $17.3 \%(n=56)$ of the participants concluded higher education. Regarding marital status, $44.3 \%$ $(n=142)$ of the participants were married, $23.7 \%(n=77)$ of them were divorced, $20.9 \%(n=65)$ were single and $11.1 \%$ $(n=36)$ were widows. A total of $58.8 \%(n=191)$ of the participants did not work. 
Regarding health behavior data, the majority stated that they did not do breast self-examination $(31.1 \% ; n=101)$ followed by rarely $(20.9 \% ; n=68)$, monthly $(20 \% ; n=65)$, weekly $(18.5 \%$; $n=60)$ and other $(9.5 \% ; n=31)$. Still, the majority declared doing a mammogram exam yearly $(69.2 \% ; n=222)$, followed by within more than one year $(18.1 \% ; n=58)$ and by those who do not $(12.8 \% ; n=41)$. About $30.2 \%(n=98)$ had a family history of breast cancer.

\section{Instruments}

Sociodemographic, clinical and health behavior questionnaire. This instrument includes information such as sex, sexual orientation, age, education, marital status, number of children, work activity, health behaviors (frequency of routine consultations with a gynecologist, frequency of breast self-examination and mammography examination) and having a family history of breast cancer.

Revised Illness Perception Questionnaire - Healthy Version (IPQ-RH) (Figueiras \& Alves, 2007). Instrument divided into three sections. The first evaluates the Identity dimension and presents a list consisting of 17 symptoms, in which the evaluator must indicate whether he/she considers that the symptom is or is not associated with the illness. The second section consists of 26 items and evaluates seven dimensions; timeline (acute/chronic), consequences, personal control, treatment control, coherence, timeline (cyclical) and emotional representation, which must be answered using a 5-point Likert scale, being 1 (strongly disagree) and 5 (strongly agree). The third section evaluates the causes dimension and presents 18 items that must also be answered based on the 5-point Likert scale. Afterward, the evaluator is asked to indicate the three main factors that cause the illness according to his/her opinion. The instrument's original language is Portuguese from Portugal, originally developed by Figueiras \& Alves (2007), showing appropriate test-retest reliability in its dimensions (.64 to .81 ).

The original instrument was adapted in the Brazilian Portuguese language by two native Brazilian researchers who are proficient in the language in both countries. Examples of adapted items are item 7 "A doença afecta seriamente" (The disease seriously affects) for "A doença afeta seriamente" (The disease seriously affects) and item 8 "A doença tem sérias consequências económicas" (The disease has serious economic consequences) for "A doença tem sérias consequências econômicas" (The disease has serious economic consequences). In the validation study, the seven factors of the original version were identified by the exploratory factor analysis. Besides, 13 of the 18 original items in the illness causes section were also subjected to factor analysis, in which the dimensions/factors psychological assignments and general risk factors were identified.

\section{Procedures}

Data collection. The sample, from two different research projects on women's health, was selected by convenience. Women waiting for medical consultations of different specialties were invited to participate in the study at a public Basic Health Unit of Porto Alegre (RS). They were contacted in the waiting room, study objectives were presented, and the Informed Consent Form was signed in case of participation. The instruments were applied on a single occasion, lasting for nearly 20 minutes. Caution was used to ensure that all women answered to the assessment instruments individually and without interference. The data collection period for one of the studies was from March 2015 to August 2015, and the other was from August 2017 to December 2017.

Data analysis. For the analyzes, the Software R (R Core Team, 2017) was used through the lavaan package (Rosseel, 2012). Confirmatory factor analyzes (CFAs) were conducted to test the adjustment of the empirical data structure to the seven dimensional model of the IPQ-RH (26 items) and also the two factor model of the IPQ-RH - causes of the illness (13 items). A robust version of the Weighted Least Squares (WLS), the WLSMV estimator was used, which is suitable for polytomous data and does not require the supposition of multivariate normality of the data ( $\mathrm{Li}, 2016)$. The adjustments of the models were evaluated using the following indicators: $\chi 2 / \mathrm{df}$ (chisquare/degrees of freedom), CFI (Comparative Fit Index), TLI (Tucker-Lewis Index), RMSEA (Root Mean Square Error of Approximation) and SRMR (Standardized Root Mean Square Residual). Values of $\chi 2 / \mathrm{df}$ are suitable when less than 2. CFI and TLI values above .95 suggest excellent adjustments, while values above .90 indicate that the adjustment quality is satisfactory. RMSEA and SRMR less than .05 indicate a good adjustment, and values less than .08 indicate an acceptable adjustment (Hu $\&$ Bentler, 1999). To evaluate internal consistency, McDonald's Omega $(\Omega)$ and Cronbach's alpha $(\alpha)$ coefficients were calculated. These coefficients are acceptable when the value is $>.60$ (Dunn, Baguley, \& Brunsden, 2014; Nunnally, 1978).

Descriptive statistics (means, standard deviation, medians, and quartiles) of the items and factors scores were calculated, as well as Spearman (rho) correlations among all factors and with the age of the participants. Also, possible differences in the scores of the IPQ-RH were tested according to education, to the frequency in which the participants perform the breast self-examination (never/rarely $v s$. weekly/ monthly) and the mammography (does not perform $v s$. in one year period $v s$. more than one year), and according to the presence or absence of a breast cancer family history. In these analyzes, Mann-Whitney and Kruskal-Wallis tests were used, with post hoc of Dunn and correction of Bonferroni. The level of significance adopted was $5 \%$.

\section{Ethical Considerations}

Ethical procedures for research with human beings were adopted following Resolution no. 466/12 and Resolution on Research Ethics for Human and Social Sciences no. 510/16. The data come from two research projects on women's health that were approved by the Ethics Committee of the Universidade do Vale do Rio dos Sinos (CAEE no. 39147114.83001.5338 and 66411717.5.3001.5338). 


\section{Results}

\section{IPQ-RH (26 items)}

The multivariate distribution of the data was considered non-normal (Mardia - skewness of 1475.72, $p>.05$; kurtosis: $886.28, p<.05$ ). The values of the adequacy adjustment indexes of the seven factor model for the IPQ-RH (26 items) confirmed a satisfactory adequacy of the CFA $(\chi 2=358.24 ; \chi 2 /(278)=1.29, p<.01$; $\mathrm{CFI}=.92 ; \mathrm{TLI}=0.91 ; \mathrm{RMSEA}=.03(90 \%$ CI $[.02-.04])$;
SRMR $=.06$ ). Table 1 shows the standardized loads of the items in their respective factors.

The reliability coefficients indicated satisfactory internal consistency for the total IPQ-RH (McDonald $\Omega=.72$; Cronbach $\alpha=.74$ ) and for the timeline acute/ chronic dimensions (McDonald $\Omega=.61$; Cronbach $\alpha=.61$ ); coherence (McDonald $\Omega=.74$; Cronbach $\alpha=.72$ ) and emotional representation (McDonald $\Omega=.72$; Cronbach $\alpha=.74)$. The treatment control, consequences, timeline cyclical and personal control dimensions showed values of McDonald $\Omega$ and Cronbach $\alpha<.60$, varying from .50 to .59 .

Table 1

Factor loadings on the Seven Factors of the IPQ-RH $(N=320)$

\begin{tabular}{|c|c|c|c|}
\hline Dimension & Item & $M(S D)$ & Factor loadings \\
\hline \multirow{5}{*}{$\begin{array}{l}\text { Timeline Acute/ } \\
\text { Chronic }\end{array}$} & Breast cancer lasts a short time & $3.52(1.01)$ & .372 \\
\hline & Breast cancer is a more permanent than temporary illness & $3.47(1.00)$ & .484 \\
\hline & Breast cancer lasts a long time & $3.26(1.00)$ & .657 \\
\hline & Breast cancer passes quickly & $3.72(.87)$ & .436 \\
\hline & I think breast cancer lasts for the rest of the life & $2.43(1.11)$ & .377 \\
\hline \multirow[t]{4}{*}{ Consequences } & Breast cancer is a serious condition & $4.53(.62)$ & .258 \\
\hline & $\begin{array}{l}\text { Breast cancer seriously affects the way the patient sees himself/herself as } \\
\text { an individual }\end{array}$ & $4.26(.68)$ & .301 \\
\hline & Breast cancer causes serious financial consequences & $3.98(.82)$ & .620 \\
\hline & Breast cancer causes difficulties for those who are close to the patient & $4.09(.78)$ & .644 \\
\hline \multirow[t]{3}{*}{ Personal Control } & $\begin{array}{l}\text { What the patient does can determine whether breast cancer improves or } \\
\text { worsens }\end{array}$ & $3.93(.84)$ & .380 \\
\hline & The evolution of breast cancer depends on the patient himself/herself & $3.80(.92)$ & .604 \\
\hline & The patient has the power to influence the evolution of breast cancer & $3.70(.95)$ & .626 \\
\hline \multirow[t]{3}{*}{ Treatment Control } & Treatment is effective in curing breast cancer & $3.90(.96)$ & .389 \\
\hline & $\begin{array}{l}\text { The negative effects of breast cancer can be prevented or avoided by } \\
\text { treatment }\end{array}$ & $3.93(.69)$ & .572 \\
\hline & Breast cancer treatment can control the illness & $4.10(.57)$ & .230 \\
\hline \multirow[t]{3}{*}{ Coherence } & Symptoms of breast cancer confuse me & $3.60(1.00)$ & .523 \\
\hline & Breast cancer is a mystery to me & $3.01(1.19)$ & .772 \\
\hline & I do not understand breast cancer & $3.06(1.16)$ & .765 \\
\hline \multirow[t]{3}{*}{ Timeline Cyclical } & Symptoms of breast cancer come and go in cycles & $3.18(.97)$ & .504 \\
\hline & Breast cancer is very unpredictable & $3.84(.84)$ & .564 \\
\hline & Breast cancer goes through phases in which it improves or worsens & $3.65(.86)$ & .654 \\
\hline \multirow{5}{*}{$\begin{array}{l}\text { Emotional } \\
\text { Representation }\end{array}$} & I get depressed when I think about breast cancer & $3.39(1.27)$ & .849 \\
\hline & When I think about breast cancer, I get disturbed & $3.08(1.28)$ & .850 \\
\hline & If I had breast cancer, I would feel angry & $2.90(1.23)$ & .509 \\
\hline & I get anxious when I think about breast cancer & $3.17(1.23)$ & .770 \\
\hline & Breast cancer makes me feel scared & $3.65(1.24)$ & .666 \\
\hline
\end{tabular}

\section{IPQ-RH - Causes of the Illness (13 items)}

The hypothesis of multivariate normality of the data was violated (Mardia - skewness: 21.60, $p>.05$; kurtosis: 221.86, $p<.05$ ), thus the data distribution was considered non-normal.
The adjustment indexes values of the two-factor model showed excellent CFA adequacy: $(\chi 2=82.11 ; \chi 2 /(78)=1.05$, $p=.06$; CFI $=.97$; TLI $=.97$; RMSEA $=.00(90 \% \mathrm{CI}$ $[.00-.02]) ;$ SRMR $=.05)$. Standardized factor loadings in their respective factors are shown in Table 2. 
Table 2

Factor loadings in the Two Factors of the IPQ-RH - Causes of the Disease $(N=320)$

\begin{tabular}{|c|c|c|c|}
\hline Dimension & Item & $M(S D)$ & Factor loadings \\
\hline \multirow[t]{6}{*}{ Psychological Attributions } & Stress and worry & $3.62(1.06)$ & .573 \\
\hline & Emotional state & $3.55(1.06)$ & .631 \\
\hline & Personality & $2.69(1.08)$ & .625 \\
\hline & Personal attitudes & $3.46(1.11)$ & .617 \\
\hline & Family problems & $3.12(1.16)$ & .728 \\
\hline & Overwork & $2.57(1.08)$ & .538 \\
\hline \multirow[t]{7}{*}{ General Risk Factors } & Heredity & $4.18(.81)$ & .218 \\
\hline & Overweight & $3.04(1.12)$ & .476 \\
\hline & Diet & $3.46(1.07)$ & .634 \\
\hline & Pollution & $2.97(1.09)$ & .536 \\
\hline & Poor medical care in the past & $3.89(.88)$ & .358 \\
\hline & Ageing & $2.64(1.05)$ & .326 \\
\hline & Immunity & $3.91(.81)$ & .329 \\
\hline
\end{tabular}

The reliability of the illness causes subscale, considering the total score, was satisfactory (McDonald $\Omega=.79$; Cronbach $\alpha=.80)$. The subscales psychological assignments (McDonald $\Omega=0.79$; Cronbach $\alpha=0.80$ ) and general risk factors (McDonald $\Omega=.60$; Cronbach $\alpha=.60$ ) also showed reliability values within the reference limits. The correlations among the IPQ-RH dimensions varied between weak and moderate (Table 3). Specifically, it highlights the moderate correlation of emotional representation with treatment control and psychological attributions. No significant correlations were found between the IPQ-RH dimensions and age.

No differences were found in the instrument's scores according to the frequency of mammography. On the other hand, differences were found according to educational level, frequency of breast self-examination and presence/absence of a family history of the disease (Table 4). The women with higher education had lower scores in the treatment control, coherence, timeline cyclical and emotional representation dimensions. Regarding breast self-examination, women who performed it on a weekly or monthly basis had higher scores in the consequences, personal control, treatment control and emotional representation dimensions compared to those who never or rarely do the self-examination. Finally, women with a family history of breast cancer showed a greater perception of the consequences of the illness and a lower score in terms of coherence and timeline cyclical.

Table 3

Correlations between the IPQ-RH Dimensions $(N=320)$

\begin{tabular}{|c|c|c|c|c|c|c|c|c|c|c|c|}
\hline Factors & $M(S D)$ & Min-Max & 1 & 2 & 3 & 4 & 5 & 6 & 7 & 8 & 9 \\
\hline 1. T_A/C & $16.40(3.10)$ & $6-25$ & 1 & & & & & & & & \\
\hline 2. $\mathrm{C}$ & $16.86(1.94)$ & $11-20$ & $.16^{* *}$ & 1 & & & & & & & \\
\hline 3. PC & $11.42(1.95)$ & $3-15$ & -.08 & $.15^{* *}$ & 1 & & & & & & \\
\hline 4. TC & $11.93(1.47)$ & $7-15$ & $-.16^{* *}$ & $.18^{* *}$ & $.27^{* * *}$ & 1 & & & & & \\
\hline 5. $\mathrm{CO}$ & $9.66(2.69)$ & $3-15$ & .02 & $.15^{* *}$ & .01 & $.13^{*}$ & 1 & & & & \\
\hline 6. TC & $10.66(1.93)$ & $4-15$ & .03 & .09 & $.14^{* * *}$ & .10 & $.35^{* *}$ & 1 & & & \\
\hline 7. ER & $16.18(4.93)$ & $5-25$ & .04 & $.14^{* * *}$ & $-.15^{* *}$ & .04 & $.48^{* *}$ & $.28^{* * *}$ & 1 & & \\
\hline 8. PA & $19.00(4.58)$ & $6-30$ & .05 & $.17^{* *}$ & $-.13^{*}$ & .06 & $.32^{* *}$ & $.18^{* *}$ & $.68^{* *}$ & 1 & \\
\hline 9. GRF & $24.09(3.71)$ & $15-35$ & -.06 & .03 & -.03 & .01 & $.13^{*}$ & .03 & $.41^{* *}$ & $.5^{* * *}$ & 1 \\
\hline
\end{tabular}

Note. $\mathrm{T}$ A/C $=$ timeline acute/chronic; $\mathrm{C}=$ consequences; $\mathrm{PC}=$ personal control; $\mathrm{TC}=$ treatment control; $\mathrm{CO}=$ coherence; $\mathrm{TC}=$ timeline cyclical; $\mathrm{ER}=$ emotional representation; $\mathrm{AP}=$ psychological attributions; $\mathrm{GRF}=$ general risk factors; ${ }^{*} p<.05 ; * * p<.01$. 


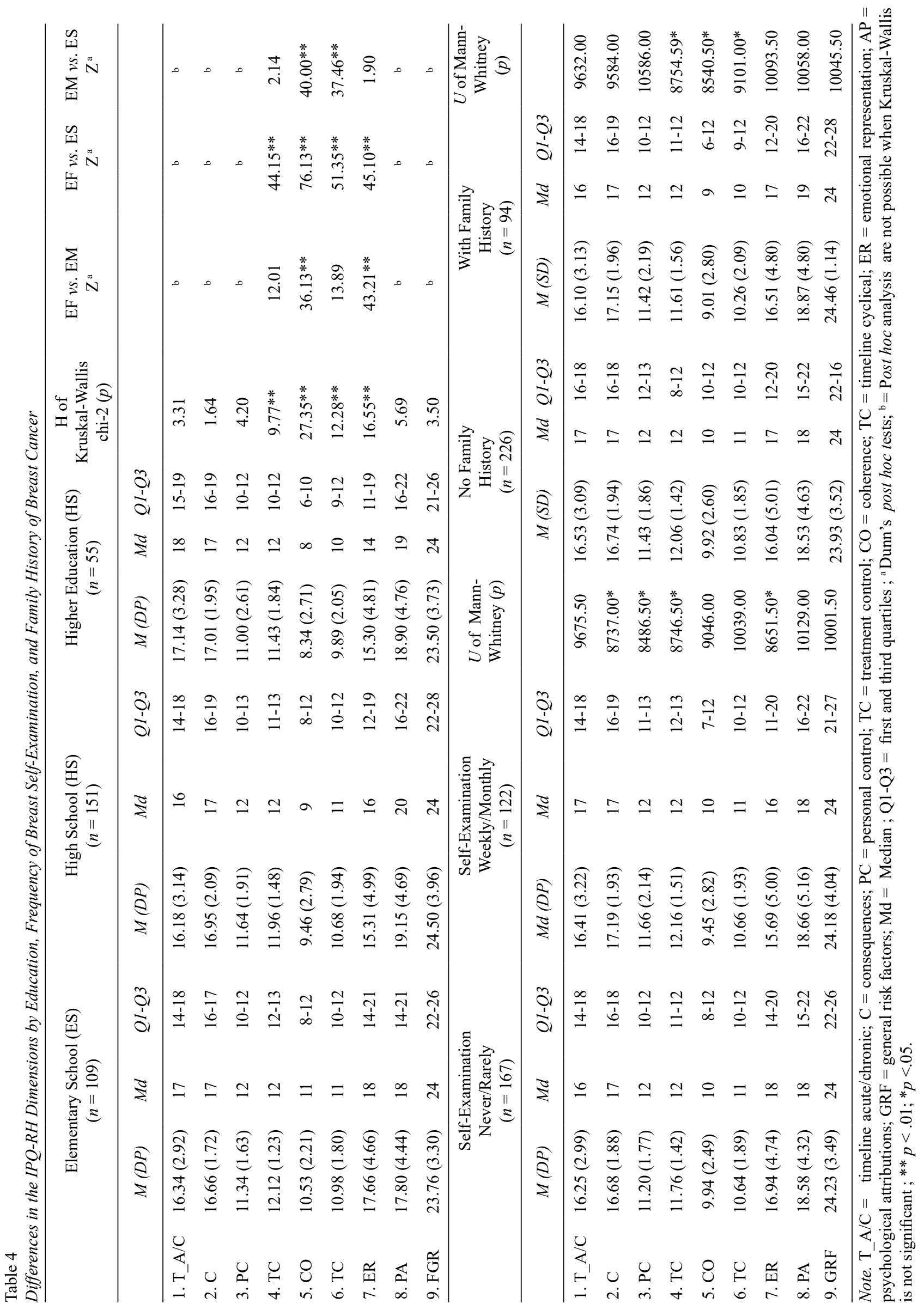




\section{Discussion}

This study sought to analyze the psychometric properties (validity of the internal structure and reliability) of IPQ-RH, a questionnaire used worldwide in research that assesses the individual's illness perception. The version used confirmed the respective factor structures for the illness perception subscales and causes of the illness, as in the original article (Figueiras \& Alves, 2007).

As for reliability, the treatment control, consequences, timeline cyclical and personal control dimensions showed values below the cutoff point. This may have occurred due to the small number of items in these dimensions, which tends to undermine the accuracy estimate (Rammstedt \& Beierlein, 2014; Ziegler, Kemper, \& Kruyen, 2014). In this case, a test-retest reliability study in future research may be more appropriate. The causes of illness subscale obtained satisfactory reliability indexes for both factors, the same occurred when considering the total score of the two sections of the questionnaire.

Moderate correlations were observed among the emotional representation dimension and the coherence dimensions, general risk factors and psychological attributions. These results show that the negative emotional impact perceived (emotional representation dimension) by healthy women is associated with a low perception of knowledge about the illness (coherence dimension) and causal attribution to psychological and general factors. In line with these results, Fischer et al. (2013) found moderate correlations between coherence and emotional representation in women diagnosed with breast cancer, proving that this association can be observed even after the experience of diagnosis and treatment. Thus, educational interventions and focusing on knowledge about the illness are necessary, considering that the less women know about the illness, the more threatening they understand it. As for the impact, the negative emotional representation of breast cancer can influence health behaviors, reducing adherence to cancer prevention in healthy women and increasing the levels of emotional distress in women with the diagnosis. Moderate correlations were also observed between psychological assignments and general risk factors $(\mathrm{r}=.50)$. These results confirm the correlations found in the study by Rozema, Völlink and Lechner (2009), although the authors investigated such associations in a clinical sample of breast cancer.

In this study it was found that women with higher education had less treatment control, greater knowledge about the disease (coherence), less timeline cyclical and a less negative emotional representation of the illness. Lizama et al. (2016) found that women with higher education showed greater knowledge about breast cancer. Thus, possibly because they have greater access to information and resources for the treatment of the illness, they believe more in the possibility of cure through treatment. Still, the attribution to the illness as cyclical is associated with the widespread perception of cancer as an unpredictable and often incurable illness, evoking fear from the illness (Vrinten et al., 2016).
Participants who indicated to do breast self-examination showed an illness perception of more serious consequences, more negative emotional representation, and greater personal and treatment control. The threatening perception of cancer can be disturbing and have a negative emotional impact (Otaran \& Castro, 2019), however, on the other hand, it can have a positive impact on adherence to preventive behaviors, such as self-examination, increasing the perception of personal control over the illness.

Ultimately, women with a family history of breast cancer indicated a greater perception of knowledge about the illness, greater perception of treatment control and timeline cyclical. This suggests that those who experienced the treatment of a family member possibly feel they know better about the illness and perceive the impacts of the treatment as more negative. Freitas and Weller (2019), in a study with healthy Brazilian women, revealed that those with a family history had more appropriate knowledge about the illness. On the other hand, Otaran and Castro (2019) investigated the illness perception in healthy women with and without a family history of breast cancer found that the only difference between the groups was related to the perception of less control of treatment by women with a cancer history. Still, women with a family history of cancer perceive the illness as cyclical, considering the possibility of recurrence and the fear associated with this risk (McGinty, Small, Laronga, \& Jacobsen, 2016).

The present study provides evidence of IPQ-RH construct validity, enabling its use in research and clinical practice aimed at healthy women, investigating their breast cancer perceptions. The study has limitations, and one of them is because it was carried out from a sample already collected from two different projects on women's health, which made it impossible to perform test-retest analyzes or correlation analyzes with instruments that measure a similar construct. Also, both studies that provided the sample in this article used samples of convenience which, besides making it impossible to generalize the data, implies a bias in the sample's regionalization (women using Basic Health Units in Porto Alegre). Since they all were women who used the Health Unit, it is possible that this is another bias, since women who do not use the public health system are not represented. Future research can evaluate the psychometric properties of the instrument in different medical conditions and populations with different age groups.

\section{Referências}

Alwhaibi, M., Lilly, C. L., Hazard, H., \& Kelly, K. M. (2019). Breast cancer survivors perceptions of prevention versus control of future cancer recurrence. International Journal of Breast Cancer, 2019, 2652180. doi: $10.1155 / 2019 / 2652180$

Broadbent, E., Petrie, K. J., Main, J., \& Weinman, J. (2006). The Brief Illness Perception Questionnaire. Journal of Psychosomatic Research, 60(6), 631-637. doi:10.1016/j.jpsychores.2005.10.020 
Dunn, T. J., Baguley, T., \& Brunsden, V. (2014). From alpha to omega: A practical solution to the pervasive problem of internal consistency estimation. British Journal of Psychology, 105(3), 399-412. doi:10.1111/bjop.12046

Figueiras, M. J., \& Alves, N. C. (2007). Lay perceptions of serious illnesses: An adapted version of the Revised Illness Perception Questionnaire (IPQ-R) for healthy people. Psychology \& Health, 22(2), 143-158. doi:10.1080/14768320600774462

Fischer, M. J., Wiesenhaan, M. E., Does-den Heijer, A., Kleijn, W. C., Nortier, J. W. R., \& Kaptein, A. A. (2013). From despair to hope: A longitudinal study of illness perceptions and coping in a psycho-educational group intervention for women with breast cancer. British Journal of Health Psychology, 18(3), 526-545. doi:10.1111/j.2044-8287.2012.02100.x

Freitas, A. G. Q., \& Weller, M. (2019). Women's knowledge about risk factors of breast cancer in a Brazilian community. Women \& Health, 59(5), 558-568. doi:10.1080/03630242.2018.1516266

Gibbons A, Groarke A, Sweeney K. Predicting general and cancer-related distress in women with newly diagnosed breast cancer. BMC Cancer. 2016; 16(1):935. doi:10.1186/s12885-016-2964-z

Hu, L. T., \& Bentler, P. M. (1999). Cutoff criteria for fit indexes in covariance structure analysis: Conventional criteria versus new alternatives. Structural Equation Modeling: A Multidisciplinary Journal, 6(1), 1-55. doi:10.1080/10705519909540118

Jones, C. J., Smith, H., \& Llewellyn, C. (2016). A systematic review of the effectiveness of interventions using the Common Sense Self-Regulatory Model to improve adherence behaviours. Journal of Health Psychology, 21(11), 2709-2724. doi:10.1177/1359105315583372

Kaptein, A. A., Schoones, J. W., Fischer, M. J., Thong, M. S., Kroep, J. R., \& van der Hoeven, K. J. (2015). Illness perceptions in women with breast cancer-a systematic literature review. Current Breast Cancer Reports, 7(3), 117-126. doi:10.1007/s12609-015-0187-y

Leventhal, H., Bond-Deren, S., Breland, J., Hash-Converse, J., Phillips, L. A., Leventhal, E. A., \& Cameron, L. D. (2012). Modeling health and illness behavior. In A. Baum, T. A. Revenson, \& J. Singer (Eds.), Handbook of health psychology (2nd ed., pp. 3-35). New York, NY: Routledge.

Leventhal, H., Brissette, I., \& Leventhal, E. A. (2003). The common-sense model of self-regulacion of health and illness. In L. D. Cameron \& H. Leventhal (Eds.), The selfregulation of health and illness behaviour (pp. 42-65). New York, NY: Routledge.
Leventhal, H., Nerenz, D. R., \& Steele, D. J. (1984). Illness representation and coping with health threats. In A. Baum, S. E. Taylor, \& J. E. Singer (Eds.), Handbook of psychology and health: Vol. 4. Social psychological aspects of health (pp. 219-252). Hillsdale, NJ: Lawrence Erlbaum.

Li, C. H. (2016). Confirmatory factor analysis with ordinal data : Comparing robust maximum likelihood and diagonally weighted least squares. Behavior Research Methods, 48(3), 936-949. doi:10.3758/s13428-015-0619-7

Lizama, N., Rogers, P., Thomson, A., Slevin, T., Fritschi, L., Saunders, C., \& Heyworth, J. (2016). Women's beliefs about breast cancer causation in a breast cancer case-control study. Psychooncology, 25(1), 36-42. doi:10.1002/pon.3869

McGinty, H. L., Small, B. J., Laronga, C., \& Jacobsen, P. B. (2016). Predictors and patterns of fear of cancer recurrence in breast cancer survivors. Health Psychology, 35(1), 1-9. doi:10.1037/hea0000238

Ministério da Saúde. (2019a). Câncer de mama no Brasil: Mortalidade está abaixo da média mundial. [Breast cancer in Brazil: Mortality is below the world average.] Retrieved from https://saude.gov.br/noticias/agenciasaude/45879-cancer-de-mama-no-brasil-mortalidadeesta-abaixo-da-media-mundial

Ministério da Saúde. Instituto Nacional de Câncer. (2019b). Câncer de mama - versão para Profissionais de Saúde. Retrieved from https://www.inca.gov.br/tipos-de-cancer/ cancer-de-mama/profissional-de-saude

Moss-Morris, R., Weinman, J., Petrie, K., Horne, R., Cameron, L., \& Buick, D. (2002). The Revised Illness Perception Questionnaire (IPQ-R). Psychology \& Health, 17(1), 1-16. doi:10.1080/08870440290001494

Nogueira, G. S., Seidl, E. M. F., \& Tróccoli, B. T. (2016). Análise fatorial exploratória do questionário de percepção de doenças versão breve [Exploratory factor analysis of the Illness Perception Questionnaire Brief Version (Brief IPQ)]. Psicologia: Teoria e Pesquisa, 32(1), 161-168. doi:10.1590/0102-37722016011871161168

Nunnally, J. C. (1978). Psychometric theory (2nd ed.). New York, NY: McGraw-Hill.

Otaran, P. M., \& Castro, E. K. (2019). Percepção de doença e distress emocional numa amostra de mulheres brasileiras com e sem histórico familiar de câncer de mama [Illness perception and emotional distress in a Brazilian women sample with and without cancer family history]. Avances en Psicología Latinoamericana, 37(2), 331-343. doi:10.12804/revistas.urosario.edu.co/apl/a.6894

R Core Team. (2017). R: A language and environment for statistical computing. Vienna, Austria: R Foundation. Retrieved from http://www.r-project.org/ 
Rammstedt, B., \& Beierlein, C. (2014). Can't we make it any shorter? The limits of personality assessment and ways to overcome them. Journal of Individual Differences, 35(4), 212-220. doi:10.1027/1614-0001/a000141

Rosseel, Y. (2012). lavaan: An R package for structural equation modeling. Journal of Statistical Software, 48(2), 1-36. doi:10.18637/jss.v048.i02

Rozema, H., Völlink, T., \& Lechner, L. (2009). The role of illness representations in coping and health of patients treated for breast cancer. Psychooncology, 18(8), 849857. doi:10.1002/pon. 1488

Seabra, C. R., Armiliato, M. J., Souza, L. V., Otaran, P., Peuker, A. C. W. B., \& Castro, E. K. (2018). Breast cancer prevention: What women think about the illness, its risks and self-care. Psico, 49(3), 266-273. doi:10.15448/19808623.2018.3.27311

Vrinten, C., McGregor, L. M., Heinrich, M., von Wagner, C., Waller, J., Wardle, J., \& Black, G. B. (2016). What do people fear about cancer? A systematic review and meta-synthesis of cancer fears in the general population. Psychooncology, 26(8), 1070-1079. doi:10.1002/pon.4287

Weinman, J., Petrie, K. J., Moss-Morris, R., \& Horne, R. (1996). The illness perception questionnaire: A new method for assessing the cognitive representation of illness. Psychology \& Health, 11(3), 431-445. doi:10.1080/08870449608400270

Ziegler, M., Kemper, C. J., \& Kruyen, P. (2014). Short scales - five misunderstandings and ways to overcome them. Journal of Individual Differences, 35(4), 185-189. doi:10.1027/1614-0001/a000148

Rebeca Veras de Andrade Vieira is a Postdoctoral fellow (PNPD- CAPES) in Psychology at Universidade do Vale do Rio dos Sinos, São Leopoldo-RS, Brazil.

Juliana Burges Sbicigo is a Postdoctoral in Psychology at Universidade Federal do Rio Grande do Sul, Porto AlegreRS, Brazil

Maria Julia Armiliato is a Master's candidate for the Psychology Graduate Program at Universidade do Vale do Rio dos Sinos, São Leopoldo-RS, Brazil.

Elisa Kern de Castro is an Associate Professor of the Universidade Lusíada de Lisboa, Portugal.

Maria João Figueiras is an Associate Professor at Zayed University, College of Natural and Health Sciences, Psychology Department, Abu Dhabi, United Arab Emirates.
Authors' Contribution:

All authors made substantial contributions to the conception and design of this study, to data analysis and interpretation, and the manuscript revision and approval of the final version. All the authors assume public responsibility for the content of the manuscript.

Associate editor:

Luciana Mourão Cerqueira e Silva

Received: Sep. 02, 2019

1st Revision: Mar. 02, 2020

2nd Revision: Jun.15, 2020

Approved: Jun. 26, 2020
How to cite this article:

Vieira, R. V. A., Sbicigo, J. B., Armiliato, M. J., Castro, E. K., \& Figueiras, M. J. (2021). Psychometric properties of the Brazilian version of the Revised Illness Perception Questionnaire for Healthy Women (IPQ-RH). Paidéia (Ribeirão Preto), 31, e3103.doi:https://doi. org/10.1590/1982-4327e3103 